\title{
Design of Bizmart UOB Bank Financial Service Promotion
}

\author{
Ira Wirasari ${ }^{1}$ and Muhammad Ichwan ${ }^{2}$ \\ ${ }^{1}$ School Of Creative Industries, Universitas Telkom, Bandung,Indonesia \\ ${ }^{2}$ Universitas Telkom, Bandung, Indonesia \\ 1irawirasari@gmail.com,2ichwanzulfriansyah5@yahoo.com
}

\begin{abstract}
Indonesia has many entrepreneurs with quite creative business fields. Even Small and Medium Enterprises or SMEs can become one of the social wheels in Indonesia to cover such dense employment. However, many of these SMEs fail to develop. This was conveyed in dpr.go.id's official page that SMEs in Indonesia stagnated from $70 \%-80 \%$ due to lack of guidance and education in managing their partnerships. This high number makes the author want to raise a breakthrough online financial technology from Bizsmart that is able to manage finances, schedules, payroll and meet with clients. The author also uses qualitative methods and uses creative strategies so that this application information can reach the public with media that is easily accessible by the community. Therefore, it is hoped that this promotion of planning can reduce the stagnation rate of SMEs in Indonesia and the Bizsmart application is more widely used by business people.
\end{abstract}

Keywords: Design, promotion, financial, Small and Medium Enterprises

\section{INTRODUCTION}

According to WeAreSocial.com Indonesian people's activities in E-Commerce to find product information is $45 \%$ and those who make shopping decisions are $45 \%$. Product categories in E-Commerce spent by Indonesians are fashion \& beauty, electronics, food, furniture, toys, digital music and video games. Seeing the needs of Indonesian people who are very active in this digital world, making businesses expand their business wings to the shutter of the digital world. Progress in Financial Technology (Fintech) is an innovation that can make competition in traditional financial methods certainly in financial services. This innovation becomes a concentration of financial management with world-based technology.

According to Lawrance Loh as the head of UOB's banking business, SME activists are aware of the world of technology and business with the digital world, but when they try to explore the world of technology to improve business operations, they are not aware of using resources more effectively. The study findings from the results of the ASEAN SME Transformation Study survey by the United Overseas Bank (UOB) can be concluded that many SMEs do not optimize technology spending.

Bizsmart targets at least around 600 SMEs to join. This financial service provides general advantages such as preventing leakage and data distortion, reducing human resource errors, helping to produce data and reports that will be used as a company analysis. Bizsmart provides 
a differentiator from other financial programs, under the auspices of a UOB Bank, Bank reconciliation is made easier.

From the results of the explanation above it can be assumed that with the advancement of digital, the business to be carried out between MSMEs and UOB Banks is highly developed if applied to the digital world. But financial management, which is one of the important factors, is a failure for SMEs in Indonesia. $70-80 \%$ of SMEs in Indonesia experience stagnation due to poor financial management problems.

Seeing the high amount of stagnation in SMEs and seeing a good innovation in technologybased business and the internet, encourages the author to make a promotion to raise the Bizsmart financial service program is better known in the community. With this promotion the author will try to give awareness to the UKM activists regarding this application. This is necessary because the problem they are experiencing is in the minds of the UKM activists who are not aware of the usefulness of this program. So they need a promotion to make SMEs aware. This promotion is expected to make SME movers aware that the existence of digital technologybased financial management is able to take care of the business they are going through, so that the SME movers can focus on their core business.

Financial technology is no longer a new office or company that competes in banking. But an evolution of advances in technology, the internet and banking. Financial technology is useful for changing people's thinking patterns about all the information about banking so far.

According to Carl Von Clausewits (1780-1831) Strategy is the use of battles to win wars. While Creative is the process of creating new things that are new and have not been created by others and provide a different added value.

It can be concluded that the Creative Strategy itself is a draft of a new plan that has not existed before and provides new added values in it that will be used against competitors of a product.

The message strategy is how the brand relations with the media delivered. Discussing about consumer insight, design to the implementation of its message [9]. Promotion Strategy is a way to use good promotion so that Advertising and promotion complement each other which will create a brand [9].

Consumer behavior is a process for making decisions based on individuals whose purpose can be to assess, obtain, and use goods and services.

Several things can affect consumer behavior;

1. Cultural factors, including social class, sub-culture, and culture;

2. Social factors, which are the role of status in the family;

3. Psychological factors, namely motivation, perception, and trust.

\section{METHOD}

Qualitative research is a process of naturalistic inquiry that seeks in-depth understanding of social phenomena within their natural setting. It focuses on the "why" rather than the "what" of social phenomena and relies on the direct expe-riences of human beings as meaning-making agents in their every day lives [11].

In designing the service promotion of Bizmart, the author devised a promotional strategy aimed at increasing the brand awareness of the target audience of Bizmart. With the hope that the attitude and behavior of the user can change according to what the producer wants, the audience who initially did not know eventually become customers and remember the brand of Bizmart. The author uses an integrated promotional strategy between several elements of 
thepromotional mix, namely Direct Marketing and Advertising. Combining several promotional mix components into one whole that can support each other in achieving the goals of designing the Bizmart service promotion, which is to increase brand awareness.

\section{RESULT AND DISCUSSION}

The promotion strategy that I use is to raise brand awareness to the audience. The promotion used is Direct Marketing with the main media Event. This is done because by using the event there will be a direct interaction with the audience such as talk shows, booths, consulting and so on. This main media promotion was pushed with various other promotional media. Like using social media, ads, billboards, ambient media and others.

Creative strategy is a design of ideas or ideas that are pure and new in creating visual styles, visualizing the idea to determine how the idea is placed. Creative strategies can be obtained through data held by the product and the target audience. These two data sources can then be solved through small ideas through brainstorming, SWOT analysis, AOI analysis to describe the audience in detail. By getting small ideas a message will be delivered to the audience.

The design of this promotion is carried out for business / SME movers with an ideal age range of 25-40 years. Next is an analysis of the target audience such as wants, needs, fears and expectations in business.

From the above analysis, then there are some important points that become a keyword insight;

1. Business movers want business to flourish

2. Business drivers need loyal Human Resources

3. Business drivers expect innovation to reduce the risk of financial management.

With the keywords that have been obtained from crossing products and the target audience. Then created several messages for this Bizsmart promotion;

1. Manage your business with friends. (manage your business with friends)

2. Your business becomes smart. (Your Business BizSmart)

3. be smart with your business (Bizsmart with your business)

The message raised at the promotion to be conveyed to the audience is "your business becomes smart" which means that with Bizsmart the scope in managing your business will be easier so that the business can move forward and be able to take risks in developing, this is what is interpreted as smart business. This promotion is supported by the be smart tagline from the smarter. It means to be smart from something smart. Financial Service is a smart innovation for doing business, so that business people can be smart from smart innovation, namely financial service. The \#BizsmartFromTheSmarter and \#YourBusinessBizsmart support hashtags will be used in all promotional designs.

Based on the message that has been obtained by Your Business Bizsmart "Your business is becoming smart", then we need a way so that this message can reach the audience. Therefore, researchers chose Event as the main media for designing promotions. The name of this event is Transform your business into smart business which means "Turn your business into a smart business". Smart raised on the message and the theme of the event means businesses who dare to take risks and step forward. The style of this event is like Expo Food \& Beverages. 

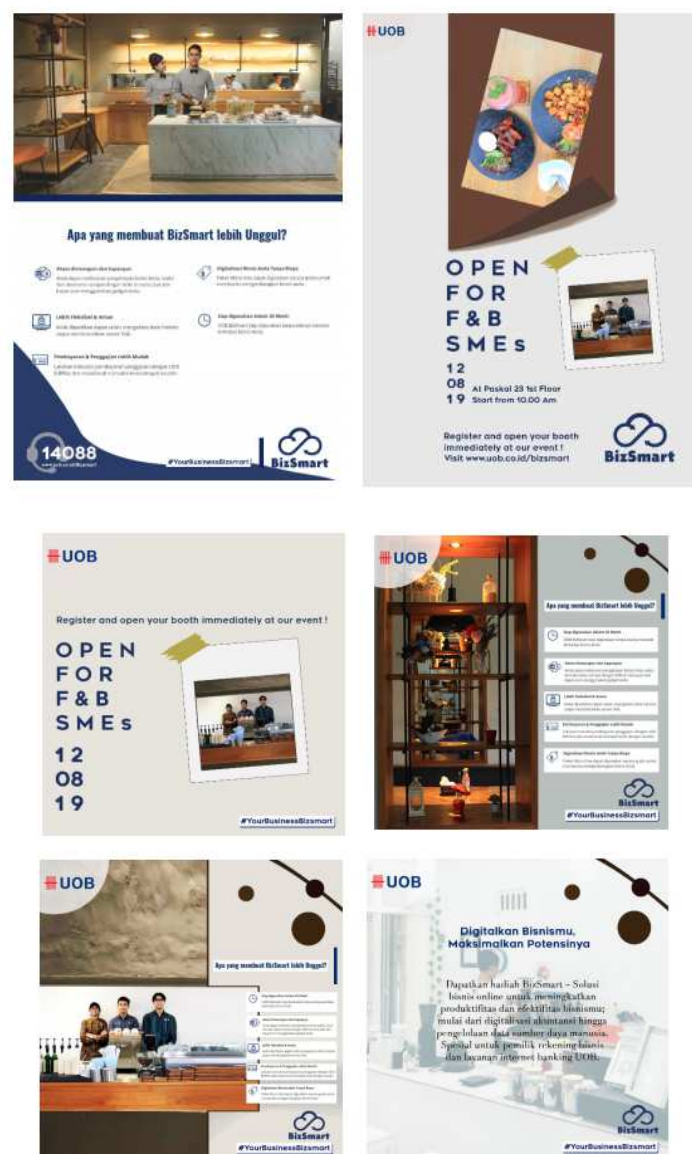

Figure 1 Result of the design Source: Author

Media strategy is how existing messages and visuals can be conveyed to the audience. Media cannot be arbitrary, of course it must be precise, effective and also based on activities that do not directly interfere with the target audience.

The strategy used is AISAS, where this strategy introduced Dentsu due to the development of the internet and technology where the important points referring to Share became the main points in this modern world for a product to be better known. Before the advent of AISAS due to internet and technological advances, the strategy was called AIDCA (attention-interestDesire-Conviction-Action). Whereas AISAS (attention-interest-search-action-share).

Event as the main media, is intended to gather Food \& Beverages business people to make a sale directly during the event, or like Expo F\&B. Where SMEs who want to open a booth at the event can Sign Up Bizsmart will then get rewards going forward for their business. The event called Transform Your Business into Smart Business, is a food and beverages festival event. Where F\&B SMEs can gather and open booths by signing up with Bizsmart. Reference taken is from the 2018 Bandung coffee event. Tagline Be Smart from the Smarter.The event will be held in Bandung, precisely at Paskal 23, because it has an appeal and is not too formal, so thatthe 
SMEs owner can be relaxed and not rigid to treat him.It will be free, because it sees a survey where the needs of the audience who really need input in doing business, and bizsmart as a new product, can enter the scope of the audience to increase awareness.If we compare with the creative strategies used in Antangin Fit advertising [13], it can be concluded that Antangin Fit advertising use creative promotion strategies through social media because the digital revolution has changed many aspects of human life. Then the creative strategy used by UOB is a strategy that is suitable for the various changes in human life in the current digital era.
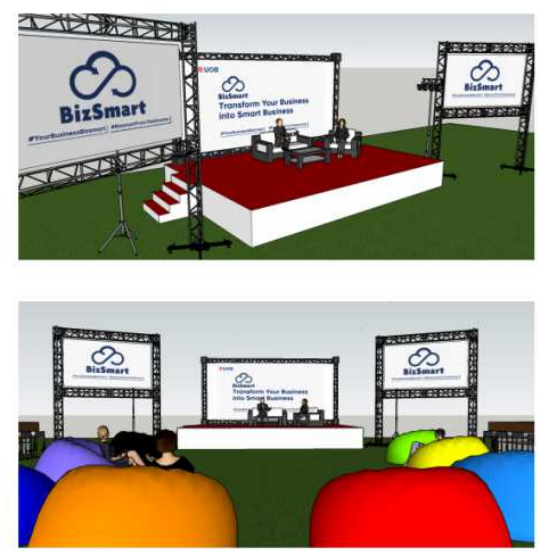

Figure 2 Result design for event Source: Authhor

\section{CONCLUSION}

The author can conclude that the digital and online-based financial program is a new thing and needs education that is able to guide its users. Bizsmart as one of the Financial Service programs is not yet known among business people like SMEs. This is evidenced by the small number of SMEs joining the Bizsmart program. One of the factors is the absence of intensive promotion from Bizsmart, plus the lack of education about this program, thus making Bizsmart unknown and even the target itself is still afraid and lay about this Financial Service program.

Through data analysis and theoretical considerations that have been collected, the design of the promotion is the right thing to raise this Bizsmart program. Create a positioning for Bizsmart, create a new message to be accepted at the target audience, and create an Event that creates a positive impact on the target to join Bizsmart. With this Bizsmart promotion design will create a new promotional message for Bizsmart that can influence and understand the deepest desires of the target audience.

Bizsmart as a Financial Service program which has advantages to make Bank reconciliation easier in Indonesia should be able to highlight its advantages compared to its competitors. In addition, Bizsmart should be able to create a promotion that is able to create an impact that makes its target audience join Bizsmart. The promotion that is given must give a strong message to the target audience. The author also suggests that Bizsmart direct the promotion from business to business. Of course what will be given when the promotion is running is a good impact for businesses that are targeted by Bizsmart. 


\section{REFERENCES}

[1]. BPS (2012-2014). Perkembangan data Usaha Mikro, Kecil, Menengah (UMKM) dan usaha besar (UB) 2012 dan 2014.

[2]. Barthes, Roland. 1974. S/Z. Penerjemah Richard Miller. New York: Hill and Wang, buku asli diterbitkan tahun 1970.

[3]. Barthes, Roland. The Semiotics Challenge. New York: Hill and Wang,1998.

[4]. DarmaprawiraW.A., Sulasmi, Warna: teori dan kreativitas penggunanya ed. Ke-2. Bandung: Penerbit ITB, 2002.

[5]. David, Fred R. Strategic Manajement, Konsep Manajemen Strategis edisi 12. Jakarta: Salemba Empat,2012.

[6]. Keraf, Gorys. Diksi dan Gaya Bahasa. Jakarta: Gramedia Pustaka Utama, 2010.

[7].Kertamukti, Rama.Strategi Kreatif dalam Kreatif. Jakarta: PT RajaGrafindo Persada. Moriarty,2015.[8]. Kotler, PhilipManajemen Pemasaran Edisi Milenium. Jakarta: PT Prenhallindo,2000.

[9]. Moriarty, Nancy Mitchell, William Wells. Advertising. Jakarta: Kencana, 2011.

[10]. Sugiyono. Metode Penelitian. Bandung: Afabeta, 2005.

[11]. Sujarweni, V Wiratna. Metodologi Penelitian, Pustaka Baru, Yogyakarta, 2014.

[12]. Moriarty, Sandra.Advertising. Jakarta:Prenadamedia Grup,2015.

[13]. Wirasari, Ira. Kajian Bahasa Iklan Antangin Fit Pada Media Sosial, Jurnal Demandia Vol.03, No.02,pp. 145-159, 2018.

[14]. Wirasari, Ira. The Political Advertising of Women'S Skin Colours in Indonesia, Journal of Art and Design Studies, IISTE Vol.10, 2013. 